\title{
COMPARISON OF MACHINE LEARNING CLASSIFICATION ALGORITHM ON HOTEL REVIEW SENTIMENT ANALYSIS (CASE STUDY: LUMINOR HOTEL PECENONGAN)
}

\author{
Jaja Miharja'; Jordy Lasmana Putra ${ }^{2}$, Nur Hadianto ${ }^{3}$ \\ Computer Science \\ STMIK Nusa Mandiri Jakarta, Indonesia \\ www.nusamandiri.ac.id \\ 1jajamiha1210@nusamandiria.ac.id ${ }_{2}^{2}$ balakusalo@gmail.com; ${ }^{3}$ dion.hadianto@gmail.com
}

\begin{abstract}
Analysis of hotel review sentiment is very helpful to be used as a benchmark or reference for making hotel business decisions today. However, all the review information obtained must be processed first by using an algorithm. The purpose of this study is to compare the Classification Algorithm of Machine Learning to obtain information that has a better level of accuracy in the analysis of hotel reviews. The algorithm that will be used is $k-N N(k$ Nearest Neighbor) and NB (Naive Bayes). After doing the calculation, the following accuracy level is obtained: $k$-NN of $60,50 \%$ with AUC value of 0.632 and NB of $85,25 \%$ with an AUC value of 0.658 . With these results can be determined the right algorithm to assist in making accurate decisions by business people in the analysis of hotel reviews using the $N B$ Algorithm.
\end{abstract}

Keywords: Sentiment Analysis, Hotel Review, Naive Bayes, $k$-Nearest Network, Machine Learning

\begin{abstract}
Abstrak - Analisis sentiment review hotel sangat membantu untuk dijadikan sebagai tolak ukur atau acuan untuk mengambil keputusan pelaku bisnis hotel saat ini. Akan tetapi semua informasi review yang didapat harus diolah terlebih dahulu dengan menggunakan Algoritma. Tujuan penelitian ini adalah untuk membandingkan Algoritma Klasifikasi dari Machine Learning untuk memperoleh informasi yang tingkat akurasi lebih baik dalam analisis review hotel. Algoritma yang akan digunakan adalah k-NN (k-Nearest Neighbor) dan NB (Naive Bayes), Setelah melakukan perhitungan diperoleh tingkat akurasi berikut ini : k-NN sebesar $60,50 \%$ dengan nilai AUC adalah 0,632 dan NB Sebesar $85,25 \%$ dengan nilai AUC adalah 0,658. Dengan hasil tersebut dapat ditentukan algoritma yang tepat untuk membantu dalam pengambilan keputusan yang akurat oleh pelaku bisnis pada analisa review hotel menggunakan Algoritma NB.
\end{abstract}

Kata Kunci: Analisis Sentimen, Review Hotel, Naive Bayes, k-Nearest Network, Machine Learning

\section{INTRODUCTION}

The current hotel business competition which very much makes hoteliers do a variety of ways in order to remain able to survive in the competition. One way is to continue to evaluate through reviews obtained from visitors both online and offline in order to find out the extent of customer satisfaction and the lack of services provided by the hotel businessman to the visitors.

In research conducted by (Yordanova \& Kabakchieva, 2017) revealed that the initial challenge when analysing responses from hotel guests was to estimate the opinions expressed in hotel reviews by classifying those responses as positive or negative feedback, in (Utami et al., 2018). This can be overcome by applying analysis sentiment. Sentiment Analysis is a process carried out with the aim to determine the contents of a dataset in the form of text (documents, sentences, paragraphs, etc.) that are positive, negative or neutral (Kontopoulos et al., 2013) on (Effendy, 2015).

The second challenge is imagining results with the aim of extracting business knowledge obtained through the Business Intelligence tool (Utami et al., 2018). Sentiment analysis according to (Zhang \& Liu, 2017) also referred to as opinion mining is a field of study that analyzes people's opinions, sentiments, evaluations, judgments, attitudes, and emotions towards entities such as products, services, organizations, individuals, problems, events, topics, and various attributes. Sentiment analysis (Sipayung et al., 2016) is a method for understanding, extracting, and processing review or textual data to get the sentiments contained in a review. Reviews can be divided into 3 types, namely positive, negative and neutral. By using sentiment analysis the company can find out the customer's response to a product or service through the feedback provided.

Several previous studies lately, there have been many studies related to review analysis, including film review research with a focus on 
classifying reviews into two classes, namely positive and negative using the Support Vector Machine (SVM) algorithm, the accuracy obtained by $71,87 \%$ and increased to $77 \%$ by using hybrid Particle Swarm Optimization (PSO) (Basari et al., 2013).

Mining Opinion in hotel review uses the Naive-Bayes algorithm conducted by (Muthia, 2016). This study shows the effect of using the ngram feature on Naive Bayes with an increase in accuracy to $87 \%$. Other researchers compared the classification algorithm between Support Vector Machine (SVM), Naive Bayes (NB), and Artificial Neural Network for film reviews with the highest accuracy produced by SVM with an accuracy value of $81.10 \%$. While the results of the comparison of feature selection algorithms between information gain, chi-square, forward selection, and backward elimination obtained the highest results in information gain using the top $\mathrm{k}$ parameter with a value of $\mathrm{k}=200$ and the accuracy results of $84.57 \%$ (Chandani et al., 2015).

Research conducted (Dey et al., 2016) discuss the two machine learning algorithms, namely $\mathrm{K}$ Nearest Neighbor (K-NN) and Naive Bayes and compare the two accuracies as a whole. The results showed in the film review, Naive Bayes gave much better results than $\mathrm{K}-\mathrm{NN}$ but both hotel reviews gave almost the same performance. Research related to the classification of sentiments regarding hotel reviews on social media using several algorithms such as Decision Tree Learning, K-NN, and Neural Networks. By using a 20-200 balanced dataset, the highest accuracy is obtained at $85.90 \%$ (Yordanova \& Kabakchieva, 2017).

Although the number of studies on text mining applications has increased, in marketing, there are still research gaps regarding customer assessment preferences through text mining procedures (Dirsehan, 2016). Currently, there are many methods used to get the highest accuracy in the field of text mining research. Adding features to several methods has also been carried out. But still different results are shown by different studies. And there is no fixed conclusion that can prove the best algorithm for research involving sentiment analysis. Therefore this study aims to get the best algorithm among several algorithms that can be used in sentiment analysis testing related to hotel reviews. In order to test sentiment analysis, especially those conducted on offline reviews that are used by business people to find out directly reviews from visitors get optimal results.

\section{MATERIALS AND METHODS}

In this study, the process of compiling two machine learning algorithms will use a hotel review dataset with the aim to determine the extent of accuracy of the two machine learning algorithms.

The material or dataset used in this study uses primary data taken from Luminor Hotel Pecenongan from January 2019 - March 2019 with 600 reviews consisting of 400 positive reviews and 400 negative reviews, which are used as training data. As for the testing data used as many as 400 reviews, consisting of 200 positive and negative reviews respectively, before the review dataset is used first, text processing is performed to prepare a document or dataset in the form of text to be ready for use.

In the comparison process itself, the method that the researchers propose uses the following two algorithms in machine learning namely NB (Naïve Bayes) and k-NN (k-Nearest Neighbor) to compare the accuracy of the dataset classification in the form of hotel review text. Stages of the comparative process that will be carried out by researchers can be seen in Figure 1 below:

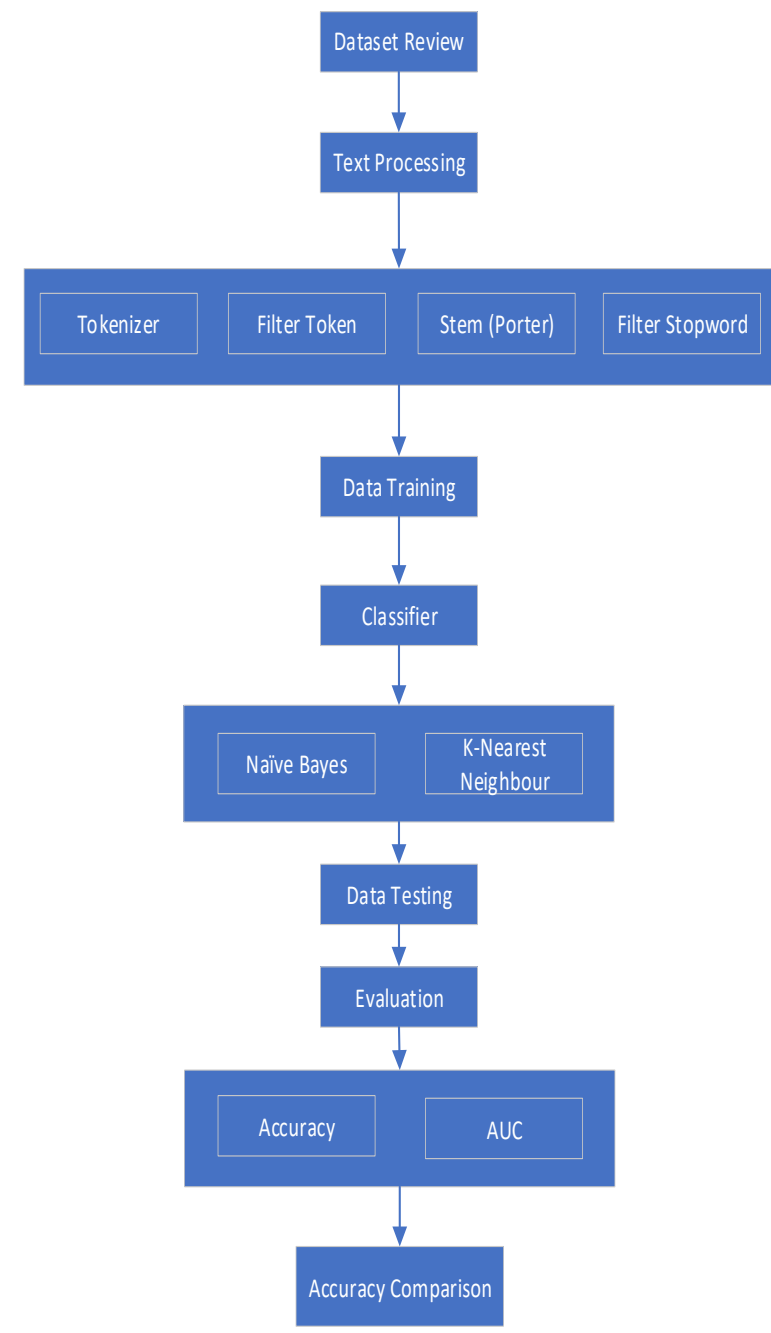

Source: (Miharja et al., 2020)

Figure 1 Comparison of Classification Algorithms 
Explanation of the comparative process conducted by researchers in Figure 1 above through seven stages, namely dataset review, text processing, data training, classifier, data testing, evaluation and accuracy comparison.

The first stage is to review data from the dataset obtained and normalize it before the dataset is processed in text processing. In the text processing tokenizer, the process is done to eliminate punctuation, symbols or other characters that are not letters. After the next tokenizer filter token, Stem (porter) and stop-word filter. The end result of the text processing can be seen in the following table:

Table 1 Final Results of the Text Processing Process

\begin{tabular}{|c|c|}
\hline Review & $\begin{array}{c}\text { Text Processing } \\
\text { Result }\end{array}$ \\
\hline $\begin{array}{lr}\text { Hotel } & \text { nyaman, } \\
\text { pelayanan ramah, } & \text { raran saya ditambah } \\
\text { saran } & \text { kolam renang }\end{array}$ & $\begin{array}{l}\text { Hotel nyaman layan } \\
\text { ramah saran saya } \\
\text { tambah kolam renang }\end{array}$ \\
\hline $\begin{array}{l}\text { Pelayanan bagus, } \\
\text { lobby bagus, sangat } \\
\text { disayangkan tidak ada } \\
\text { kolam renang }\end{array}$ & $\begin{array}{l}\text { Layan bagus loby } \\
\text { bagus saying tidak ada } \\
\text { kolam renang }\end{array}$ \\
\hline $\begin{array}{l}\text { Pelayanan } \\
\text { memuaskan, makanan } \\
\text { enak saya senang } \\
\text { menginap disini }\end{array}$ & $\begin{array}{l}\text { Layan puas makan } \\
\text { enak saya senang inap } \\
\text { sini }\end{array}$ \\
\hline $\begin{array}{l}\text { Semua bagus, hanya } \\
\text { kalau malam ada } \\
\text { suara musik }\end{array}$ & $\begin{array}{lcc}\text { Semua } & \text { bagus } & \text { hanya } \\
\text { malam } & \text { ada } & \text { suara } \\
\text { music } & & \\
\end{array}$ \\
\hline $\begin{array}{l}\text { Exhaust dikamar } \\
\text { smoking harus lebih } \\
\text { baik, untuk kenyaman } \\
\text { kamar smoking }\end{array}$ & $\begin{array}{l}\text { Exhaust kamar } \\
\text { smoking harus lebih } \\
\text { baik untuk nyaman } \\
\text { kamar smoking }\end{array}$ \\
\hline $\begin{array}{ll}\text { Pelayanan } & \text { bagus, } \\
\text { hotel nyaman hanya } \\
\text { channel tv kurang } \\
\text { lengkap }\end{array}$ & $\begin{array}{l}\text { Layan bagus hotel } \\
\text { nyaman hanya chanel } \\
\text { tv kurang lengkap }\end{array}$ \\
\hline $\begin{array}{lr}\text { Berisik dari gedung } \\
\text { sebelah, sikat gigi } \\
\text { kualitas jelek, tempat } \\
\text { sabun } & \text { kurang } \\
\text { berkualitas } & \\
\end{array}$ & $\begin{array}{l}\text { Berisik dari gedung } \\
\text { sebelah sikat gigi } \\
\text { kualitas jelek tempat } \\
\text { sabun kurang kualitas }\end{array}$ \\
\hline $\begin{array}{l}\text { Hanya suara music } \\
\text { dari gedung sebelah } \\
\text { sangat menggangu } \\
\text { istirahat }\end{array}$ & $\begin{array}{ll}\text { Hanya suara } & \text { music } \\
\text { dari gedung } & \text { sebelah } \\
\text { sangat } & \text { ganggu } \\
\text { istirahat } & \end{array}$ \\
\hline
\end{tabular}

The next stage determines the training data before the classifier process is performed using two Naïve Bayes algorithms and a k-Nearest Neighbor. Followed by determining the testing data that will be evaluated from its accuracy level and AUC value.
The final stage is to compare the accuracy and AUC values by comparing the results of the two Naïve Bayes and K-Nearest Neighbors algorithm processes so that the algorithm can be superior and appropriate in the hotel review comparison process is the objective of this study.

To support the comparative process in this study, researchers used the RapidMiner version 5.3 tool which will produce accuracy and AUC values for each algorithm of the machine learning.

\section{RESULTS AND DISCUSSION}

1. Results Using the Naïve Bayes Algorithm

Of the 400 hotel review data, 200 positive reviews and 200 negative reviews, 187 data were predicted to be appropriate, negative and 13 data were negative but positive. In contrast, 154 data were predicted to be positive and 46 data were predicted to be positive but negative. The accuracy of using the Naïve Bayes algorithm is $85.25 \%$ with an AUC value of 0.632 .

Table 2. Confusion Matrix Naive Bayes Algorithm Accuracy : 85,25\% +/- 24,89\% (micro average :

\begin{tabular}{cccc}
\multicolumn{4}{c}{$85,25 \%)$} \\
\hline & $\begin{array}{c}\text { True } \\
\text { Negative }\end{array}$ & True Positif & $\begin{array}{c}\text { Class } \\
\text { precision }\end{array}$ \\
\hline $\begin{array}{c}\text { Pred. } \\
\text { Negatif }\end{array}$ & 187 & 154 & $55,84 \%$ \\
\hline $\begin{array}{c}\text { Pred } \\
\text { positif }\end{array}$ & 13 & 46 & $77,97 \%$ \\
\hline $\begin{array}{c}\text { Class } \\
\text { Recall }\end{array}$ & $93,50 \%$ & $23.00 \%$ & \\
\hline Source: (Miharja et al 2020$)$ &
\end{tabular}

Source: (Miharja et al., 2020)

$$
\begin{aligned}
& \text { Accuracy }=\frac{(T N+T P)}{(T N+F N+T P+F P)} \ldots \ldots \ldots \ldots \ldots \ldots \ldots \ldots \ldots \ldots \ldots \\
& \text { Accuracy }=\frac{(187+154)}{(187+13+154+46)} \\
& \text { Accuracy }=\frac{(341)}{(400)}=0,8525=85,25 \%
\end{aligned}
$$

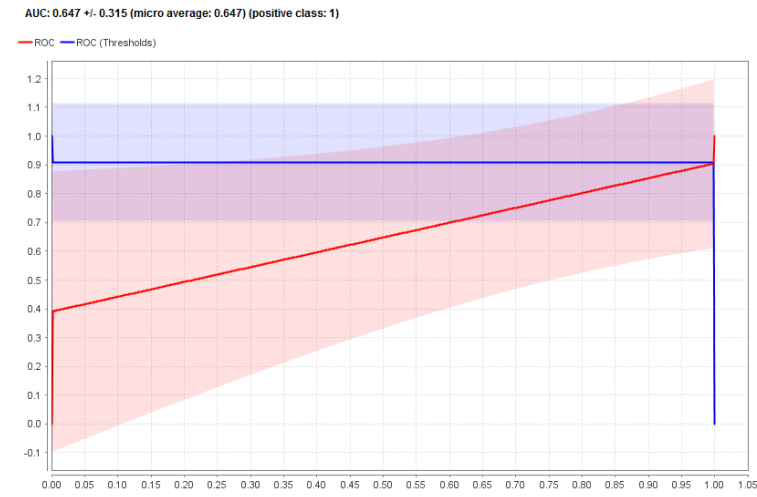

Source: (Miharja et al., 2020)

Figure 2. Naive Bayes Algorithm Graph 
Figure 2 shows the appearance of the ROC curve using the Naïve Bayes model with an AUC value of 0.632

\section{Results Using the k-Nearest Neighbor Algorithm}

Of the 400 hotel review data, namely 200 positive reviews and 200 negative reviews, as many as 133 data were predicted to be appropriate, namely negative and as much as 67 data were predicted to be negative but apparently positive. In contrast, 109 data were predicted to be positive and 91 data were predicted to be positive but negative.

The accuracy results if using the k-Nearest Neighbor algorithm is $60.50 \%$ with an AUC value of 0.658 .

Table 3. Confusion Matrix k-Nearest Neighbor Algorithm

\begin{tabular}{cccc}
\hline Accuracy & $\mathbf{6 0 , 5 0 \% + / - 2 , 9 4 \%}$ (micro average : 60,50\%) \\
\hline & $\begin{array}{c}\text { True } \\
\text { Negative }\end{array}$ & $\begin{array}{c}\text { True } \\
\text { Positive }\end{array}$ & $\begin{array}{c}\text { Class } \\
\text { precision }\end{array}$ \\
\hline $\begin{array}{c}\text { Pred. } \\
\text { Negative }\end{array}$ & 133 & 109 & $54,96 \%$ \\
\hline $\begin{array}{c}\text { Pred. } \\
\text { positive }\end{array}$ & 67 & 91 & $57,9 \%$ \\
\hline $\begin{array}{c}\text { Class } \\
\text { Recall }\end{array}$ & $66,50 \%$ & $45,50 \%$ & \\
\hline \multicolumn{2}{l}{ Source: (Miharja et al., 2020$)$}
\end{tabular}

Accuracy $=\frac{(T N+T P)}{(T N+F N+T P+F P)}$.

Accuracy $=\frac{(133+109)}{(133+67+109+91)}$

Accuracy $=\frac{(242)}{(400)}=0,6050=60,50 \%$

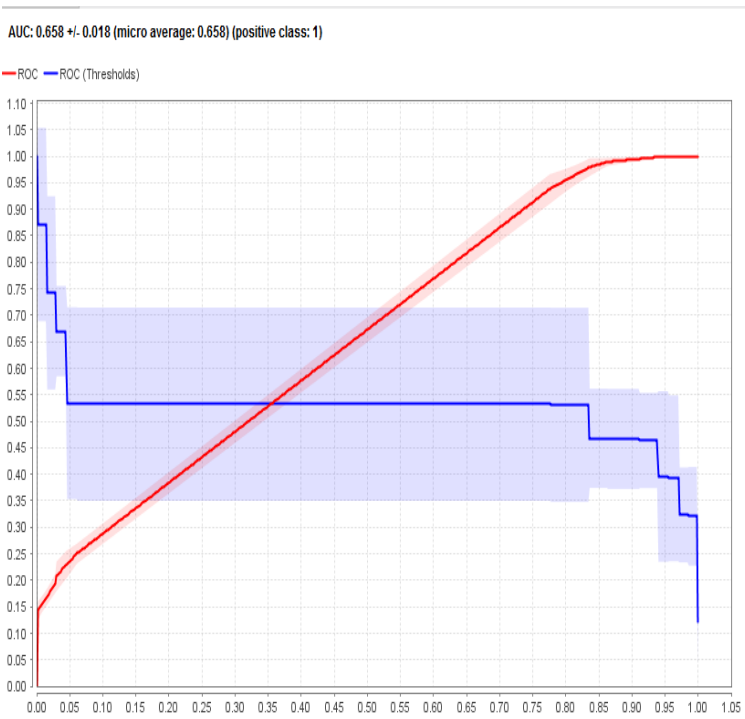

Source: (Miharja et al., 2020)

Figure 3 Graph of Area Under Curve (AUC) Algorithm K-Nearest Neighbor
Figure 3 shows the appearance of the ROC curve using the k-Nearest Neighbor model with an AUC value of 0.658 .

\section{Research Results}

The summary results of the comparison of the Naive Bayes classification algorithm and k-Nearest Neighbor are as follows:

Table 4. Comparison of Accuracy and AUC Classification Algorithms

\begin{tabular}{ccc}
\hline & Accuracy & AUC \\
\hline NB & $85,25 \%$ & 0,632 \\
\hline KNN & $60,50 \%$ & 0,658 \\
\hline
\end{tabular}

Source: (Miharja et al., 2020)

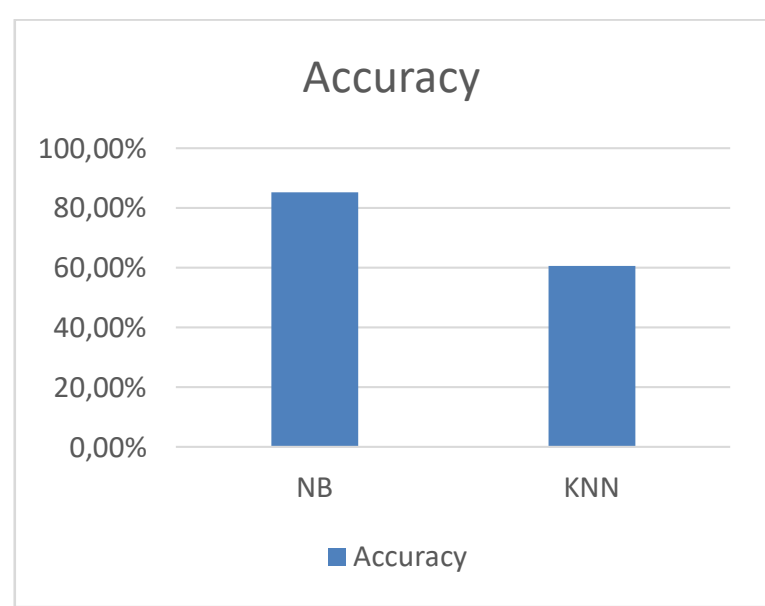

Source: (Miharja et al., 2020)

Figure 4. Classification Algorithm Graph Accuracy

Figure 4 shows a comparison graph that the Naïve Bayes algorithm with an accuracy value of $85.25 \%$ is superior to the $\mathrm{k}$-Nearest neighbor algorithm whose accuracy value is $60.0 \%$.

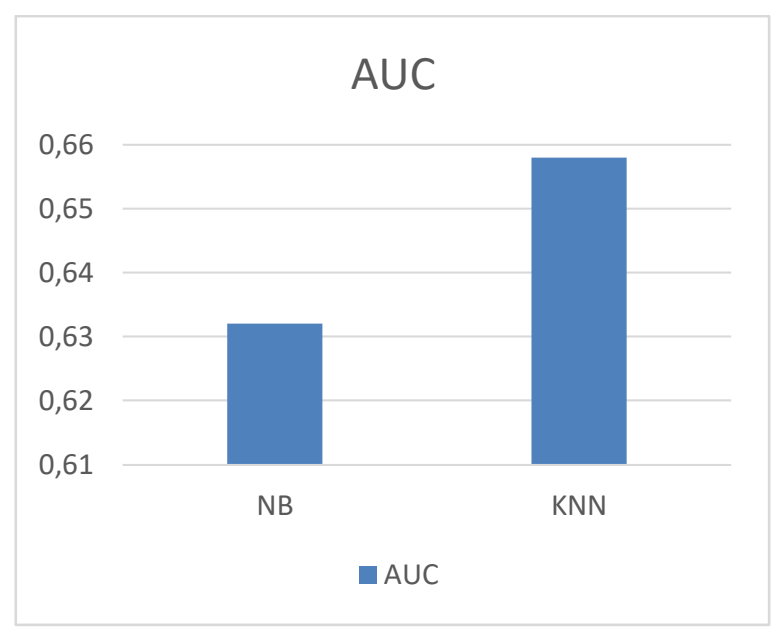

Source: (Miharja et al., 2020)

Figure 5 Graph of AUC Classification Algorithm 
Figure 5 shows a comparison graph of the AUC (Area Under Curve) value of the Naïve Bayes algorithm with a value of 0.632 and the K-Nearest Neighbor algorithm with a value of 0.658 .

\section{CONCLUSION}

The results of the comparison of classification algorithms between Naïve Bayes (NB) and k-Nearest Neighbor (k-NN) obtained NB with the best results with an accuracy of $85.25 \%$ with AUC is 0.658. These results can be used as a reference by business people to make decisions in determining business strategies.

\section{REFERENCE}

Basari, A. S. H., Hussin, B., Ananta, I. G. P., \& Zeniarja, J. (2013). OpinionMining of Movie Review Using Hybrid Method of Support Vector Machine and Particle Swarm Optimization. Procedia Engineering, 53, 453462.

https://doi.org/10.1016/j.proeng.2013.02.05 9

Chandani, V., Wahono, R. S., \& Purwanto, P. (2015). Komparasi Algoritma Klasifikasi Machine Learning Dan Feature Selection pada Analisis Sentimen Review Film. Journal of Intelligent Systems, 1(1), 56-60. http://www.journal.ilmukomputer.org/index .php?journal=jis\&page $=$ article $\& o p=$ view $\&$ pat $\mathrm{h} \% 5 \mathrm{~B} \% 5 \mathrm{D}=10$

Dey, L., Chakraborty, S., Biswas, A., Bose, B., \& Tiwari, S. (2016). Sentiment Analysis of Review Datasets Using Naïve Bayes' and KNN Classifier. International Journal of Information Engineering and Electronic Business, 8(4), 54-62. https://doi.org/10.5815/ijieeb.2016.04.07

Dirsehan, T. (2016). Text Mining in the Hospitality Sector To Extend the Motivation Theory. Conference: International Marketing Trends Conference, January, 1-13. https://www.researchgate.net/publication/2 98070052_Text_Mining_in_the_Hospitality_Se ctor_to_Extend_the_Motivation_Theory

\footnotetext{
Effendy, V. (2015). ANALISIS SENTIMEN BERBAHASA INDONESIA DENGAN PENDEKATAN LEXICON BASED (STUDI KASUS : SOLUSI PENGELOLAAN SAMPAH). Jurnal Ilmiah Komputer Dan Informatika (KOMPUTA), 4(1), 55-60. http://komputa.if.unikom.ac.id/_s/data/jurn
}

al/vol.4-no.1/8.4.1.3.2015-55-60-20899033.pdf/pdf/8.4.1.3.2015-55-60-20899033.pdf

Kontopoulos, E., Berberidis, C., Dergiades, T., \& Bassiliades, N. (2013). Ontology-based sentiment analysis of twitter posts. Expert Systems with Applications, 40(10), 40654074.

https://doi.org/10.1016/j.eswa.2013.01.001

Miharja, J., Putra, J. L., \& Hadianto, N. (2020). Independent Research Final Report.

Muthia, D. A. (2016). Opinion Mining Pada Review Buku Menggunakan Algoritma Naive Bayes. Jurnal Teknik Komputer AMIK BSI, 2(1), 1-8. http://ejournal.bsi.ac.id/ejurnal/index.php/j tk/article/viewFile/357/266

Sipayung, E. M., Maharani, H., \& Zefanya, I. (2016). Perancangan Sistem Analisis Sentimen Komentar Pelanggan Menggunakan Metode Naive Bayes Classifier. Jurnal Sistem Informasi, $\quad$ 8(1), 958-965. https://ejournal.unsri.ac.id/index.php/jsi/art icle/view/3250

Utami, L. D., Rachmi, H., \& Nurlaela, D. (2018). Komparasi algoritma klasifikasi pada analisis review hotel. Jurnal Pilar Nusa Mandiri, 14(2), 261-266.

https://doi.org/https://doi.org/10.33480/pi lar.v14i2.77

Yordanova, S., \& Kabakchieva, D. (2017). Sentiment Classification of Hotel Reviews in Social Media with Decision Tree Learning. International Journal of Computer Applications, 158(5), 1-7. https://doi.org/10.5120/ijca2017912806

Zhang, L., \& Liu, B. (2017). Sentiment Analysis and Opinion Mining. In C. Sammut \& G. I. Webb (Eds.), Encyclopedia of Machine Learning and Data Mining (pp. 1152-1161). Springer. https://doi.org/10.1007/978-1-4899-7687-1 
P-ISSN: 1978-1946 | E-ISSN: 2527-6514 | Comparison of Machine... Rank 3 Accredited Journal based on Decree SK No. 21/E/KPT/2018 DOI: $10.33480 /$ pilar.v16i1.1131 